Acta vet. scand. $1971,12,504-512$.

From the Department of Medicine, Veterinary College of Norway, Oslo.

\title{
THE SURVIVAL OF NEMATODES AND CESTODES OF SHEEP IN THE PASTURE DURING THE WINTER IN EASTERN NORWAY
}

By

\section{Oddvar Helle}

The grazing period in eastern Norway is from May to the end of October. In the winter there are usually sub-zero temperatures from November to March, and the fields are covered with snow from December to April. Under such conditions knowledge regarding the survival of parasites in the pasture is essential in the control of helminth infection in the sheep.

In USA Kates (1950) found that Ostertagia spp., Nematodirus spp. and Trichuris ovis were the only nematodes that survived the winter in significant numbers. Similar results were found by others, but some other nematode genera were found to survive severe winter climates (Swales 1940, Smith \& Archibald 1965). A survey of the literature was given by Soulsby (1965).

In the present investigation worm-free lambs were placed in paddocks on permanent sheep pastures which had been free of sheep since the previous autumn. The investigations were done on 4 farms within $40 \mathrm{~km}$ from Oslo during 4 years. Negligible anthelmintic treatment had been used for the sheep on these pastures. Most of the lambs grazed in the paddocks for short periods only, in order to prevent contamination of the paddocks with eggs voided by parasites picked up from the same paddock (Crofton 1963).

A preliminary report of a part of this material has been given (Helle 1963).

\section{MATERIAL, METHODS AND EXPERIMENTAL CONDITIONS}

The farms. Farm no. 1 kept about 20 adult sheep on cultivated pastures at a moderate stocking rate. It was used for stu- 
dies in 1959. At Farm no. 2 about 50 adult sheep with lambs had been kept for years on the same pasture at a fairly high stocking rate. The flock had occasionally been treated with phenothiazine. It was used for survival studies in 1960. Farm no. 3 had about 100 adult sheep which were kept on low ground 6 weeks in the spring and 6 weeks in the autumn. From the end of June to September the sheep were turned out on mountain grazing land. No anthelmintics had been given. This farm was used for survival studies in 1961. Farm no. 4 was the experimental farm W $\varnothing$ yen, where other investigations on sheep parasites were done, as described in other papers (Helle $1971 \mathrm{~b}$ ). The survival studies were carried out in 1963 on the pasture designated no. 1 at that farm. No anthelmintics had been given to sheep on this pasture, and lambs grazing there in 1962 developed a heavy infection with nematodes.

The paddocks were about $20 \times 20$ meters. They were separated from the surrounding pasture by a double fence with a space of $1 \mathrm{~m}$ between. No sheep had used the area that year. The paddocks were placed on ground with a good grass cover which had been regularly grazed by sheep the previous year. As far as possible no person entered the paddocks when feeding and handling the lambs.

The test lambs. These were born in concrete pens which were cleaned and washed daily. The ewes had been washed before parturition. The lambs used at Farms nos. 1, 2 and 4 were removed from their mothers soon after birth and reared on slatted floor and fed with sterilized hay, concentrates and cow's milk until they were transferred to the test paddocks, as shown in Fig. 1. In 19591 lamb was kept under these conditions for 5 months as a control of the effectiveness of the isolation. The lambs used at Farm no. 3 were left with their mothers in concrete pens until they were 3 weeks old. Most of the lambs were born in the beginning of April.

In the test paddocks the lambs were given concentrates mixed with dried skimmed milk as supplementary feeding. Fig. 1 shows the period when each lamb was in the test paddock.

After the lambs were removed from the paddocks they were kept in concrete pens which were washed daily. They were fed on hay and concentrates until they were slaughtered, as shown in Fig. 1.

Control lambs. At Farms nos. 1 and 22 or 3 lambs from the 
¿

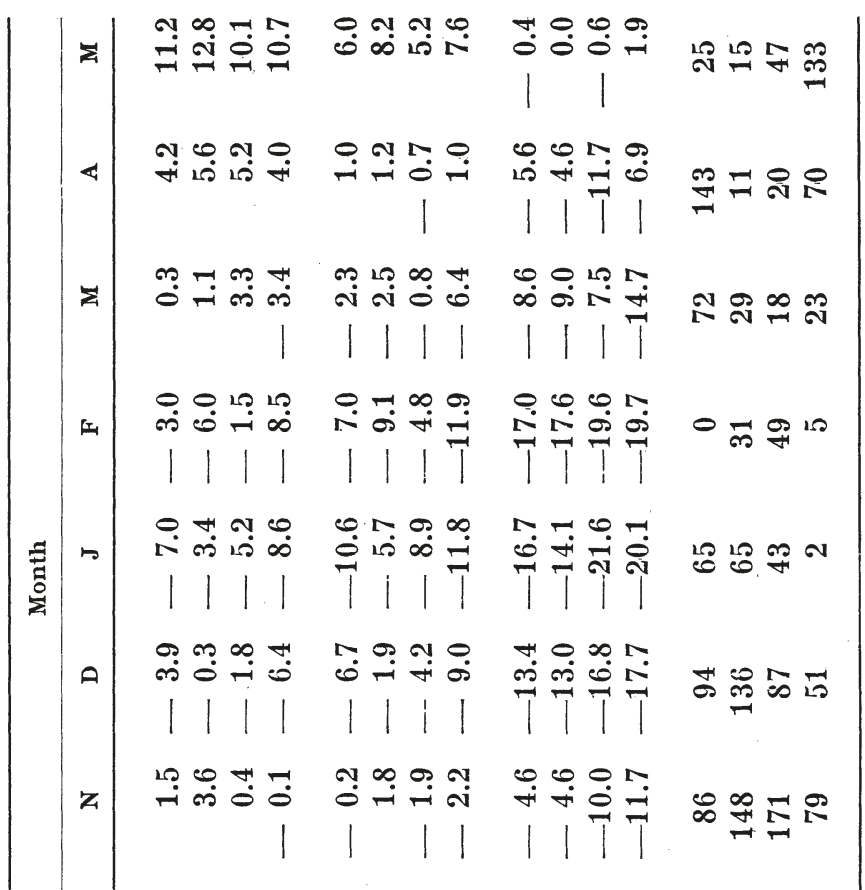

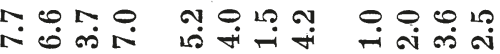

$\stackrel{\infty}{\infty} \stackrel{2}{=}$

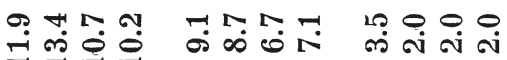

푬용ㅇㅇ

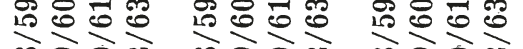

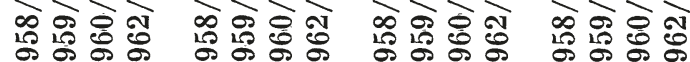

익.

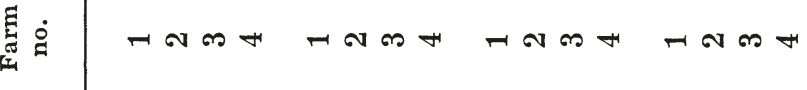

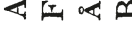
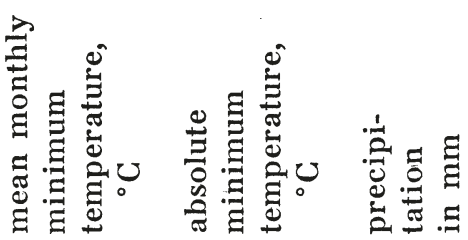
farm flock were slaughtered in the autumn in order to obtain a picture of the helminth fauna of the flock. At Farm no. 46 lambs, which had grazed in the pasture the previous year, were slaughtered in the spring of 1963. At Farm no. 3 no lambs were slaughtered, but faecal samples were examined from 4 lambs which had grazed in the pasture the previous year (1960).

Faecal examinations were done with methods described in other papers (Helle 1971 a) before and after the lambs had been in the paddocks.

Post-mortem examinations were done as described by Helle (1971 a).

Meteorological data were taken from the climatological station which was nearest to each farm. Table 1 shows the mean monthly temperature, the mean monthly minimum temperature, the absolute minimum temperature of each month and the total precipitation of the months from September to May at the respective stations.

T a b l e 2. Number of days within each month with snow cover at the climatological stations near to the experimental farms.

\begin{tabular}{|c|c|c|c|c|c|c|c|c|c|c|}
\hline \multirow{2}{*}{ Station } & \multirow{2}{*}{$\begin{array}{c}\text { Farm } \\
\text { no. }\end{array}$} & \multirow{2}{*}{ Year } & \multicolumn{8}{|c|}{ Month } \\
\hline & & & 0 & $\mathrm{~N}$ & D & $\mathbf{J}$ & F & M & $\mathbf{A}$ & $\mathbf{M}$ \\
\hline Asker & 1 & $1958 / 59$ & 0 & 1 & 24 & 31 & 28 & 31 & 16 & 0 \\
\hline Fornebu & 2 & $1959 / 60$ & 0 & 1 & 17 & 10 & 29 & 17 & 0 & 0 \\
\hline Ås & 3 & $1960 / 61$ & 0 & 10 & 12 & 31 & 22 & 4 & 6 & 0 \\
\hline Blindern & 4 & $1962 / 63$ & 0 & 13 & 29 & 31 & 28 & 31 & 11 & 0 \\
\hline
\end{tabular}

Table 2 shows the number of days with snow cover within the same months.

\section{RESULTS}

The lambs used at Farms nos. 1, 2 and 4 were free of helminth eggs in their faeces before they were turned out. In 1961 the lambs used at Farm no. 3 had some eggs of Strongyloides papillosus in the faeces before they were transferred to the paddock. Every year a few coccidia were present in the lambs before they went out. The lamb kept under worm-free conditions for 5 months in 1959 was free of helminth eggs.

Table 3 shows differential egg counts of lambs from Farm no. 3 . 
T a ble 3. Differential egg counts of nematodes in 4 lambs which had been on pasture at Farm no. 3 in 1960.

\begin{tabular}{|c|c|c|c|c|c|c|c|c|c|}
\hline \multirow[t]{2}{*}{ Date } & \multirow{2}{*}{$\begin{array}{c}\text { Lamb } \\
\text { no. }\end{array}$} & \multicolumn{8}{|c|}{ EPG } \\
\hline & & $\begin{array}{c}\text { Hae- } \\
\text { monchus }\end{array}$ & $\begin{array}{l}\text { Oster- } \\
\text { tagia }\end{array}$ & $\begin{array}{l}\text { Tricho- } \\
\text { strongylus }\end{array}$ & $\begin{array}{c}\text { Coo- } \\
\text { peria }\end{array}$ & $\begin{array}{c}\text { Buno- } \\
\text { stomum }\end{array}$ & $\begin{array}{c}\text { Cha- } \\
\text { bertia }\end{array}$ & $\begin{array}{l}\text { Nemato- } \\
\text { dirus }\end{array}$ & $\begin{array}{c}\text { Stron- } \\
\text { gyloides }\end{array}$ \\
\hline 16th & 25 & 4 & 0 & 15 & 23 & 0 & 8 & 0 & 200 \\
\hline January & 26 & 0 & 33 & 33 & 0 & 0 & 33 & 50 & 50 \\
\hline \multirow[t]{2}{*}{1961} & 27 & 0 & 19 & 112 & 131 & 0 & 188 & 100 & 900 \\
\hline & 28 & 0 & 20 & 30 & 0 & 0 & 0 & 200 & 550 \\
\hline $1 \mathrm{st}$ & 25 & 0 & 3 & 43 & 0 & 2 & 3 & 50 & 0 \\
\hline March & 26 & 2 & 5 & 89 & 0 & 2 & 1 & 0 & 0 \\
\hline \multirow[t]{2}{*}{1961} & 27 & 0 & 0 & 90 & 58 & 0 & 2 & 0 & 500 \\
\hline & 28 & 0 & 4 & 36 & 4 & 0 & 57 & 0 & 50 \\
\hline 24nd & 25 & 0 & 0 & 0 & 0 & 0 & 0 & 50 & 0 \\
\hline April & 26 & 8 & 8 & 210 & 4 & 12 & 58 & 0 & 0 \\
\hline \multirow[t]{2}{*}{1961} & 27 & 117 & 23 & 412 & 23 & 23 & 101 & 0 & 0 \\
\hline & 28 & - & - & - & - & - & - & - & - \\
\hline
\end{tabular}

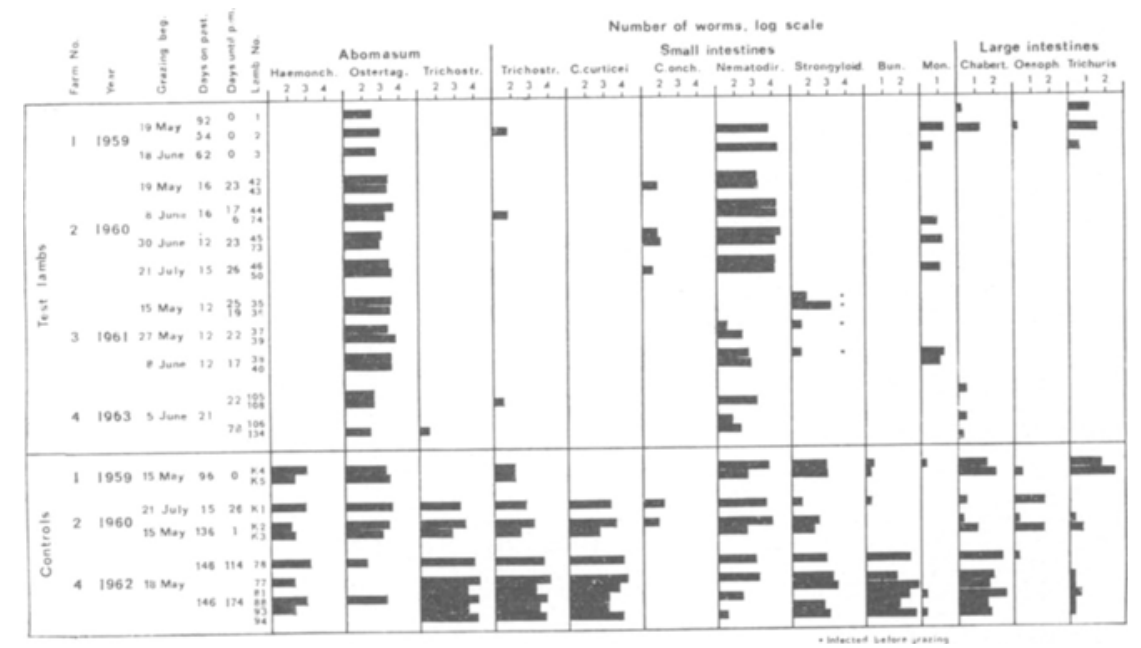

Figure 1. Helminths found in the gastrointestinal tract at postmortem examinations of the test lambs and controls. The lengths of the bars show the number of worms (log scale). The bars of the different genera of worms are placed on a horizontal row to the right of the eartag number of each lamb. The log scales of the 5 columns to the right of the figure begin with zero. All the scales to the left begin with one. 
Fig. 1 shows the number of worms found in the gastrointestinal tract of the lambs from the paddocks and the control lambs ( $\log$ scale). The number of worms was increased by 1 before transformation to logarithms.

In the test lambs Ostertagia circumcincta was found on all farms. At Farms nos. 1, 2 and 30 .trifurcata was also found. At Farm no. 4 there were a few specimens of Teladorsagia davtiani. The Trichostrongylus spp. found in the small intestines of the test lambs were $T$. vitrinus, and in the abomasum $T$. axei. The Nematodirus spp. were N. filicollis at Farms nos. 1, 3 and 4. At Farm no. 2 N. spathiger dominated, but a few $N$. filicollis were present. At Farm no. 22 specimens of Skrjabinema ovis were found in a test lamb (no. 46), and in 2 lambs 1 specimen of Protostrongylus spp. was found in the bronchii.

In the control lambs the Trichostrongylus spp. of the small intestines were $T$. vitrinus at Farm no. 1, and $T$. vitrinus and $T$. colubriformis at Farms nos. 2 and 4. At Farm no. 4 a few T. capricola were also present. The Nematodirus spp. were N. filicollis on Farms nos. 1, 3 and 4. At Farm no. 2 N. spathiger dominated above a few N.filicollis. At Farm no. 11 lamb (no. K5) had 100 Capillaria spp.

Clinical condition of the test lambs. At Farm no. 1 Lamb no. 2 died of peritonitis 12th July, having had diarrhoea for 2 weeks. Lamb no. 3 had diarrhoea at that time, and there were eggs of Nematodirus and large numbers of coccidia in the faeces. At Farm no. 2 Lambs no. 42 and no. 43 were in good condition the whole time. Lamb no. 74 had diarrhoea when it was taken in, and it died 6 days later. The other lambs on this farm were languid with soft faeces after they had been in the paddock.

At Farm no. 3 Lamb no. 36 had diarrhoea 11 days after it had been taken in, and few days later there were large numbers of coccidia in the faeces. It was sacrificed in a emaciated condition 8 days later. At Farm no. 4 all lambs from the paddock were in good condition.

\section{DISCUSSION}

With the exception of the infection with Strongyloides papillosus of the lambs used in 1961, all lambs were free of helminths before they were transferred to the paddocks. In 1959 they were in the paddock for such a long time that their nema- 
tode burden was patent and a contamination of the paddock with a subsequent reinfection may have occurred. The other years the lambs stayed in the paddock for 2-3 weeks only, and no reinfection was possible. Their nematode burden would then give an indication of the number of free-living stages which had been in the pasture. The advantage of using test lambs in survival studies is that the infectivity of the larvae is verified.

The results on the 4 farms correspond. Ostertagia spp. and Nematodirus spp. were the only nematodes which survived in large numbers. The highest number of Nematodirus was 26, 167 in Lamb no. 45 at Farm no. 2. Lamb no. 74, which died, had 16,233 Nematodirus spp. It is reasonable to regard Nematodirus spp. as the main cause of the faecal softening and the death on this farm (Soulsby 1965). At Farms nos. 1 and 3 the coccidia may have been partly responsible for the clinical symptoms. Haemonchus contortus, Cooperia curticei, Bunostomum trigonocephalum, Strongyloides papillosus and Trichostrongylus colubriformis were never found to have survived. Trichostrongylus axei, $T$. vitrinus and $O$. venulosum were found to have survived in very low numbers. Of $T$. axei and $O$. venulosum only 1 single specimen was found. A moderate survival of Cooperia onchophora, Chabertia ovina, and Trichuris ovis was found. There were, however, few specimens of Cooperia onchophora in the control lambs which shows that the level of infection in the flock concerned was low. On more heavily infected pastures a greater number of $\mathrm{C}$. onchophora in the test lambs might have been found (Smith \& Archibald 1969, Tharaldsen 1970, Nilsson 1970).

Moniezia spp could easily survive the winter in the pasture.

These results are in agreement with those of Kates (1950), Smith \& Archibald (1965), and Andersen et al. (1970). Smith \& Archibald (1965) found the same difference between Cooperia curticei and C. onchophora as found in this experiment. In Sweden Nilsson made similar findings. At Farm no. 4 there had been a heavy infection with Haemonchus contortus, Trichostrongylus axei, T. colubriformis, T. vitrinus and Cooperia curticei the previous year. The absence of H. contortus, T. colubriformis, Cooperia curticei and the low numbers of $T$. axei and $T$. vitrinus in the test lambs show that the pastures are practically free of these nematodes in the spring. In Sweden Nilsson found that T. vitrinus could survive the winter in such a number that it might be of epidemiological importance. The number of Capillaria found 
in the control lambs is too low to provide a basis for any conclusion on this genus.

The control lambs at Farms nos. 2 and 4 appeared to be heavily infected with most of the nematodes which occur in temperate regions. At Farms nos. 1 and 2 the control lambs were on pasture the same year as the test lambs. Therefore no direct information can be gained from them as to the pasture infection the previous year. They give, however, a reliable picture of the parasite fauna of the flocks.

It can be concluded that the winter in eastern Norway plays a significant part in the selection of the parasite fauna of a sheep pasture. It is of great significance that in the district concerned Haemonchus contortus, Trichostrongylus spp. and Cooperia curticei, which are important pathogens in Norwegian sheep (Naerland 1948, Helle $1971 \mathrm{a}, \mathrm{b}$ ) are almost entirely dependent upon surviving the winter within the sheep.

\section{REFERENCES}

Andersen, F. L., N. D. Levine \& P. A. Boatman: Survival of third-stage Trichostrongylus colubriformis larvae on pasture. J. Parasit. $1970,56,209-232$.

Crofton, $H$. D.: Nematode parasite population in sheep and on pasture. Tech. Comm. 35, Commonwealth Bureau of Helminthology. St. Albans 1963, 104 pp.

Helle, O.: Overvintring av de vanligste saueparasitter i Norge. (Survival over the winter of the most common helminths of sheep in Norway). 9. Nord. Vet. Congr., København 1962, Proc. 1963, $211-215$.

Helle, O.: The effect on sheep parasites of grazing in alternate years by sheep and cattle. A comparison with set-stocking, and the use of anthelmintics with these grazing managements. Acta vet. scand. 1971 a, 12, Suppl. 33.

Helle, O.: Gastrointestinal parasites in sheep on lowland pastures in eastern Norway. Acta vet. scand. 1971 b, 12, Suppl. 34.

Kates, C.: Survival on pasture of free-living stages of some common gastrointestinal nematodes of sheep. Proc. helminth. Soc. Wash. $1950,17,39-58$.

Naerland, G.: Den gastro-intestinale snylterplage hos sauen (fåret). (The gastrointestinal parasites of sheep). Skand. Vet.-T. 1948, $36,529-566$.

Nilsson, O.: Epizootologiska faktorer vid gastrointestinala nematodinfektioner hos idisslare. (Epizootological factors on nematode infection of the digestive tract of ruminants). Proc. 11th Nord. Vet. Congr., Bergen 1970, 181-183. 
Smith, H. J. \& R. Mc. G. Archibald: The overwinter survival of ovine gastro-intestinal parasites in the maritime provinces. Canad. vet. J. 1965, 6, 257-267.

Smith, H. J.\& R. Mc. G. Archibald: On the survival of overwintering bovine gastrointestinal nematode larvae during the subsequent grazing season. Canad. J. comp. Med. 1969, 33, 44-47.

Soulsby, E. J. L.: Textbook of Veterinary Clinical Parasitology. Vol. I. Helminths. Blackwell Scientific Publications, Oxford 1965, 1120 pp.

Swales, W. E.: The helminth parasites and parasitic disease of sheep in Canada. II. Notes on the effect of winter upon the free-living stages of nematode parasites of sheep on the pastures in Eastern Canada. Canad. J. comp. Med. 1940, 4, 155-161.

Tharaldsen, Jorun: Nematodes in young cattle on permanent and new pastures. Symp. Scand. Soc. Parasit. IV, Oslo 1969, Proc. in Nytt Mag. Zool. 1970, 18, 106.

\section{SUMMARY}

Using 21 worm-free lambs in paddocks on old sheep pastures on 4 farms near Oslo, it was found that Nematodirus spp., Ostertagia spp. and Moniezia spp. were the only helminths which could survive the winter in the pasture in great numbers. A few Teladorsagia davtiani, Chabertia ovina, Trichuris ovis, Cooperia onchophora and Skrjabinema ovis survived the winter. Trichostrongylus axei, $T$. vitrinus and Oesophagostomum venulosum showed a negligible ability to survive the winter in the pasture. The following species were never found to survive: Haemonchus contortus, Trichostrongylus colubriformis, Bunostomum trigonocephalum, Cooperia curticei and Strongyloides papillosus.

\section{SAMMENDRAG}

Overvintring av sauens nematoder og cestoder $i$ beiter $i$ Øst-Norge.

Ved å bruke parasittfrie lam som fors $\varnothing \mathrm{ksdyr} i$ isolerte kveer på gammelt, sterkt infiserte sauebeiter ble det funnet at Nematodirus spp., Ostertagia spp. og Moniezia spp. var de eneste nematoder og cestoder som overlevet vinteren $\mathrm{i}$ beitet $\mathrm{i}$ større mengder. Noen få eksemplarer av Teladorsagia davtiani, Chabertia ovina, Trichuris ovis, Cooperia onchophora og Skrjabinema ovis overvintret i beitet. Ubetydelig overvintring ble funnet av Trichostrongylus axei, $T$. vitrinus og Oesophagostomum venulosum. Følgende arter overlevet ikke i beitet: Haemonchus contortus, Trichostrongylus colubriformis, Bunostomum trigonocephalum, Cooperia curticei og Strongyloides papillosus. 